\title{
The Perspective of Crack Users Regarding Their Social Reintegration after the End of Treatment in Therapeutic Communities
}

\author{
Analu Schnorr, Adriana R. Binsfeld Hess, Laíssa Eschiletti Prati \\ Psychology Course at Integrated Faculties of Taquara (Faccat), Taquara, Brazil \\ Email: aschnorr@bol.com.br, laissa.prati@gmail.com
}

Received 8 February 2014; revised 2 March 2014; accepted 25 March 2014

Copyright (C) 2014 by authors and Scientific Research Publishing Inc.

This work is licensed under the Creative Commons Attribution International License (CC BY). http://creativecommons.org/licenses/by/4.0/

(c) (i) Open Access

\begin{abstract}
The use of crack cocaine has been gaining prominence in the media, because even though it's a phenomenon that emerged little more than twenty years ago, it's already an epidemic in Brazil. The large number of crack users represents a public health problem, affecting family, professional and social relations. This study investigated the perspectives of crack users regarding their social reintegration. The sample was composed of ten addicted men between the ages of 19 and 37, admitted to therapeutic communities for a social reintegration process. Semi-structured interviews were recorded, transcribed and analyzed through Content Analysis. The main results show that studying, working with addiction and meeting the expectations of family appear to be the main objectives of this period of rehabilitation. Other concerns that were quite emphasized referred to redeeming and gaining acceptance of the family, making new friends and keeping away from old ones (partners in use). As for their professional life, most respondents cited working with recovery as a possibility. Among the reintegration strategies, community work, the quest for God and church attendance, and attending healthy environments were mentioned. Calling and/or talking with friends was cited in relation to actions to be taken in case of a break down. These results indicate that there are several aspects that surround the social reintegration of crack addicts. They also indicate different paths that can help develop new interventions to assist dependents in the recovery phase.
\end{abstract}

\section{Keywords}

Crack Cocaine; Therapeutic Community; Social Reintegration

\section{Introduction}

Nowadays, drug addiction is a phenomenon that is widely known and discussed. The abuse of psychoactive sub- 
stances has become a serious social and public health problem in all the world. However, talking about the use of drugs, and about drug addiction in particular, brings to the fore issues that are directly related to the field of health care and to family and social relationships (Pratta \& Santos, 2009).

Crack has been gaining ground in the world of drugs and we still do not know what its actual effects are over time in the life of the user. When they reach the therapeutic community, the majority of users has already suffered many material and psychological losses. Many times, this situation makes them afraid to return to society (Raupp, 2006). The social ties of drug addicts are very fragile and restricted to family members who are still worried about them, suppliers of drugs and friends who also use some substances. It is also known that many of the users do not have any social or family support (Guimarães \& Aleluia, 2012; Vianna, 2008).

Because it's epidemic, Crack has been in the media spotlight. Among the Brazilian population, crack consumption is already entering its third decade. The large number of crack users represents a public health problem, which usually implies that family ties, professional relations and friendships are affected. Family, friends and the entire social support structure necessary for a "healthy" life are progressively lost during the periods of intense crack use, either because the user distances himself from the network or because those in the network reject the user. In the vast majority of cases, when the user seeks treatment, social support network is already very fragile. Crack users vanishes their entire structure (Perrenoud \& Ribeiro, 2012; Pratta \& Santos, 2009).

This study, therefore, sought to investigate the perspectives of crack users regarding their social reintegration after the end of their treatment in therapeutic communities. Specifically, try to understand how this reintegration happens, the prospects of the user with respect to his family, support network and the services offered to assist his treatment.

\section{Theoretical Foundations}

\subsection{Drug Addiction}

Drug addiction is a phenomenon that is increasingly being discussed, since substance abuse is a rising trend in whole world. However, talking about drug addiction will raise issues that are directly related to health care, which demonstrates the need for a reflection on themes such as health, disease and drugs (Pratta \& Santos, 2009).

Marlatt (1999) describes a model that discusses drug addiction as a biological disease that requires treatment and rehabilitation. He presents drug addiction as a progressive disease that has no cure, and claims that abstinence is the only alternative to contain it. This approach proposes to end the drug problem by attacking consumption by the individual with interventions that reduce his demand for drugs. It is therefore linked to education, health care and culture. Schenker and Minayo (2004), on the other hand, believe that drug addiction is related to the individual's functioning and the problems that arise in his life: both social and cognitive. Drug addiction is seen as a result of a lack of adaptation and a deficiency in the individual's abilities to deal with his social environment or with his problems (Silva, 2000).

Biological, psychological and social factors are among the main factors influencing drug addiction. Biological factors are related to the body of each individual, while psychological factors relate to the personality of each subject, as his fears, anxieties and insecurity to confront the various situations of everyday life. Under the influence of drugs, the feeling of physical and psychological frailty is replaced by consistency and strength, and by the illusion of overcoming failure: anguish is exchanged for peace (Blefari, 2002). In addition, the social factors are related to the family group and culture to which they belong.

Some authors (as Blefari, 2002; Sabino \& Cazevane, 2005) state that drug addiction is the compulsive desire for drugs at any cost, constituting both a biological (due to neuroadaptation) and psychoactive necessity. Duailibi, Severino, Barbosa and Ribeiro (2012) describe drug addiction as an altered relation between the individual and the consumption of a substance in which the former impulsively seeks immediate pleasure. The loss of acquired skills, and the difficulty in developing new ones, is also observed.

After addiction has set in, the user's organism will require increasing doses of the substance to reach the same intensity of effect. This characteristic is known as tolerance and is one of the criteria for drug addiction (American Psychiatric Association, APA, 2002). In the past, drug use may have been cultural in nature, with low concentrations of the active ingredient, but today the increasing chemical and technological knowledge have amplified its effect. Its use is indiscriminate and without control (Nonticuri, 2010). The main harmful effects of the badly adapted use of psychoactive substances include the deleterious consequences to social life, which can be 
divided into grave social problems (such as detentions and sudden separations) and chronic social problems (such as the inability to keep a job or care for family) (World Health Organization, WHO, 2004). In addition, the user's life starts to revolve around drug use, and ends up ignoring his social activities to the point of abandoning all shared life experiences with anyone who isn't part of his drug using group (APA, 2002).

Crack is a new way to present and administer cocaine: by smoking it. It has an almost immediate effect. Because it acts so fast, it leads to a very intense and compulsive consumption pattern in which binge ${ }^{1}$ use is common and recurring. Many crack addicts spend entire days and nights consuming the substance, without sleep or food, reaching a state of total physical exhaustion (Alves, Ribeiro, \& Castro, 2011).

According to Nonticuri (2010), crack is a drug that acts quickly, produces an intense craving and causes serious harm to families, communities and users. The chronic use of crack damages the cognitive functions controlling attention and mental flexibility, the ability to control, concentration and learning, among other effects that can last for long periods or even become irreversible. It proves, therefore, to be potentially destructive for the user's labor activities and its association with chronic social problems is clear (WHO, 2004).

\subsection{Support Network}

One of the essential characteristics of human beings is their social organization in the various activities that they perform. Every one born, grow up and die inserted into social groups. It's in groups that people develop their interpersonal skills, enabling themselves to perform roles that were assigned by culture, to participate in collective processes and solutions (Bechelli \& Santos, 2001).

Zimerman (1997) defines the group as something that is necessary among people, as a social interaction and some type of bond. For a group to exist, its members must first be united around a common interest. Life in groups develops bonds, the sharing of common experiences, creating the possibility of coping with a set of difficult situations that would be difficult to handle alone. He also states that it's easier to withstand the pressures of life in a group. In a group, a person can empathize with the suffering and difficulty of others, which gives rise to communication and learning.

The family can be understood as a risk and/or protection factor against the use of substances. The family is one of the many systems that make up our support network. It can be extremely significant in changing or resolving the problem (Payá, 2011). Gomes (1997) defines the family as a semi-open system, in which no one is more than anyone else, all are equal. Minuchin (1990), on the other hand, defines the family as an open system in constant transformation, trying to adapt to the various situations during its development. The goal of the family structure is to organize the family for a better interaction. It is really important look forward a family support in the treatment of drug addiction. Some studies have confirmed the effectiveness of treatments in which the family is the focus of the intervention. The results are more promising than those in which the focus of the intervention is only the patient (Schenker \& Minayo, 2004).

According to Fracasso (2011), there are five areas that are important for someone to have balanced relationships: family, friends, work/school, laws and spirituality. An imbalance of these areas can result in a dysfunctional relationship of the individual with himself and others.

Costa (2009) affirms that an extensive support network is an important protective factor. This network can be formed by family, friends, school, peers and a community that assist in adverse situations and can promote or hinder development. Social support refers to the established relationship and ties. It also means the interface between the individual and the social system, which helps the person adapt to certain situations. For Costa (2009) and Mayer (2002), social support is seen as an interactive process between a person and his/her environment, the relations that surround the individual, groups of people with whom there is contact or participation. Studies have indicated that individuals with high levels of social support have adequate self-esteem and self-confidence. They also tend to develop more adaptive strategies to deal with adverse situations (Palomar Lever, \& Cienfuegos Martínez, 2007).

Through their life history, some individuals have developed good educational and vocational skills. They may have benefited from family ties and healthy communities that were lost by the use of crack. For these individual, rehabilitation, relearning and the ability to maintain a healthy (physical and emotional) life are part of the recovery process (Fracasso, 2011).

\footnotetext{
${ }^{1}$ Described as a compulsive consumption pattern in which large quantities of a given substance are used and which can last for hours or even days, usually interrupted by physical exhaustion.
} 
Alves, Ribeiro and Castro (2011) say that the treatment of crack addicts presents several challenges and requires professionals with the necessary technical skills and availability (both emotional and regarding time). Crack addicts present problems in various areas of life: family, socio-occupational, mental and physical health. It's therefore assumed that the patient needs treatment that involves various modalities.

Therapeutic communities have been developed to provide an answer to the problems arising from drug addiction. One of these issues is having a drug free environment. The entire structure of the therapeutic community is geared towards ensuring that the patient is totally immersed in treatment, given that the focus is not only on the outcome of the treatment, but also on the consequences of a social rehabilitation in other locations outside of the therapeutic community. The therapeutic community seeks to promote a change in the personality of the patient, aiming to increase the maturity of the individual so as to facilitate his reintegration into society. This means employing values such as spirituality, responsibility, solidarity, honesty and love (Sabino \& Cazenave, 2005). The patient can be treated in a protected environment (therapeutic community) where common factors of an effective psychotherapeutic intervention are used, such as a supportive therapeutic alliance, involvement in group intervention, psycho-education strategies, schedules, rules and well delimited and structured contracts, and a combination of individual and group strategies (Alves, Ribeiro, \& Castro, 2011).

The goal of the therapeutic community is treating the disorder individually. However, it's larger objective is to transform the individual's life-style and personal identity while maintaining his full participation during recovery. This way the user can achieve the fundamental social and psychological targets, taking responsibility and helping to change him/herself. The therapeutic community has, therefore, a major challenge: first it has to separate the addict from the outside world and then, with its therapeutic program, it has to prepare him/her for reinsertion again. Little by little, the dependent must learn how to deal with the real world during the process of reintegration (Fracasso, 2011).

According to (Fracasso, 2011), when the individual accepts responsibility for his actions and starts answering for his own conduct, the recovery is considered to be a change in life style and identity, and not as merely abstinence. Bonadio (2011) says that the individual is not expected to return to his original condition, but that he moves on with new strategies for living with the limitations and possibilities that are inherent to the human condition.

Residence in the therapeutic community is a short passage, and it should be made clear that it is only one step in a general recovery process. Treatment and recovery are not the same thing, and the therapeutic community is part of the treatment and a contribution to recovery (Fracasso, 2011). The therapeutic process occurs differently in each individual. Some may stay a long time in the therapeutic community and still not have reached the final stage of treatment: reinsertion or social rehabilitation.

\subsection{Psychosocial Rehabilitation}

The terms "social rehabilitation" and "psychosocial rehabilitation" are interchangeable. One is used more often in studies focused on mental illness, while the other is employed in those dealing with drug addiction. Since drug addiction can be considered a mental illness, the term psychosocial rehabilitation was chosen for this work.

Psychosocial rehabilitation is a set of practices and actions made available in the context of treatment that seeks to promote the recovery of a person with a mental disorder. This process should not occur in a random manner (nonsystematic). Therefore, it is important that the rehabilitation process includes the structuring of a program aimed at the recovery of the user with specific objectives and goals (Bonadio, 2011). Psychosocial rehabilitation should be started when the individual stops using and begins to build a new life-style, and is incompatible with the consumption of drugs (Duailibi, Severino, Barbosa, \& Ribeiro, 2012). Saraceno (2001), cited by (Pinho, Oliveira, \& Almeida, 2008) suggest that the concept of psychosocial rehabilitation refers not only to support and friends. It's related to the elevation of the sick subject to the condition of citizen, making him/her break with the process of reclusion that is a symptom of the disease.

Rehabilitation is considered to be a public health strategy because it's a process in which the subject develops skills to live, learn, improve his/her socialization and enhance his/her autonomy. It's an important part in the therapeutic process of drug addiction, since it seeks to develop skills that will provide the user with autonomy in his/her life and that involve his/here reintegration into academic, professional, social and healthy life (Duailibi et al., 2012). Social resources, family, health and relationships are a great contribution to treatment. The process of change starts in the therapeutic community and should be maintained afterwards maintaining a good recovery. All these factors contribute to recovery in important ways (Fracasso, 2011). 
A cognitive rehabilitation that aims to organize and stimulate those functions that were impaired is important in the rehabilitation process (Salgado \& Ribeiro, 2012). In most cases, when the individual seeks help he has already suffered various losses (physical and mental, at school or work and in his family life). The loss of skills to cope in such situations increases dependency and decreases the chances of success in treatment (Duailibi et al. 2012).

Psychosocial rehabilitation, therefore, is a process that aims to emphasize the individual's qualities and potential. It can be understood as a reconstruction process in three areas: home, work and social networks. It is an intrapersonal process. It's not a standardized process, but structured according to the potential of each individual (Bonadio, 2011).

According to Vargens and colleagues (2009), developed and developing countries face several problems when promoting adequate treatment and rehabilitation for people who are addicted to illicit drugs because of the lack of treatment services. The access to the different modalities of treatment, recovery, and social and occupational reintegration must be identified and ensured in a permanent way to users, addicts and their families.

Interrupting crack use is no easy task. There are several factors that hinder this process, including the craving, the emotional state, difficulties in following outpatient treatment after hospitalization, environmental factors, narcissistic traits and denial. Araujo, Pansard, Boeira \& Rocha (2010) stresses that there are still few studies related to crack and therefore their results are not fully reliable. More longitudinal studies are necessary to better under- stand this phenomenon.

A study conducted by Costa (2001) with 12 individuals showed that $75 \%$ of respondents reported that social and family reintegration is considered to be easy or more or less easy. This study identified that personal intent, family support and employment occupy a prominent position in determining the success of reintegration.

The addiction to illicit drugs affects people, families and nations in different ways. For this reason, several studies have been developed seeking solutions to this problem. However, these studies have shown the perspective of health professionals, and not of drug users (Vargens et al., 2009). As such, this research aims to verify how the process of reintegration is experienced by the crack user and to identify the perspectives of crack users in relation to his social support network (family, and friends support for outpatient treatment) at the end of treatment.

\section{Method}

The present work is characterized as a qualitative exploratory research, since it aims to learn about a subject in depth, and to gain a significant understanding between the data and the experiences of the users. This study will work with data gathered in the context of the reality of the subjects. A qualitative research is recommended when one seeks to understand how a subject experiences and acts in a given situation (Bardin, 1977).

\subsection{Participants}

The criterion of convenience was used to select participants. Ten male drug addicts, who were internee in the Therapeutic Communities of Vale do Paranhana, and undergoing the process of psychosocial rehabilitation, participated in the study. The age of respondents ranged from 19 to 37 years of age (M = 28.80 years; $\mathrm{SD}=6.04$ years). Educational levels ranged between Incomplete Elementary Education and Incomplete College Education. The majority of participants (80\%) are single. Table 1 presents the characterization of the participants.

\subsection{Instruments}

Semi-structured interviews, produced by the author of the project, containing six open questions, were used and served to explore the topic under study. The questions referred to expectations regarding the first exit from the therapeutic community, expectations regarding the end of treatment, expectations regarding the reintegration into society, perspectives with respect to family and friends, expectations regarding professional life and expectations regarding the first new contact with society. The semi-structured interview consisted of a set of organized aspects to be investigated with each respondent, built based on basic questions that are related to the main question of this research. This type of interview provides new hypothetical questions as the conversation unfolds (Macedo \& Carrasco, 2005). 
Table 1. Characterization of the participants.

\begin{tabular}{cccccc}
\hline ID & Age (years) & Marital Status & Educational Level & Time of Drug Use & Time of Abstinence \\
\hline P1 & 37 & Married & Incomplete College & 1 Year & 7 Months \\
P2 & 36 & Single & Complete High School & 7 Years & 7 Months \\
P3 & 30 & Separated & Incomplete College & 3 Months & 8 Months \\
P4 & 26 & Single & Complete Elementary & 7 Years & 8 Months \\
P5 & 29 & Single & Incomplete High School & 4 Years & 1 Year and 1 Month \\
P6 & 27 & Single & Incomplete High School & 4 Years & 7 Months \\
P7 & 21 & Single & Complete Elementary & 8 Years & 7 Months \\
P8 & 28 & Single & Incomplete Elementary & 8 Years & 6 Months \\
P9 & 19 & Single & Complete Elementary & 3 Years & 9 Months \\
P10 & 35 & Single & Complete High School & 6 Years & 7 Months \\
\hline
\end{tabular}

\subsection{Procedures for Data Collection}

This project is linked to a larger project called "Monitoring the Continuity of Treatment in Outpatient Services for Crack Users after Treatment in Therapeutic Communities of Vale do Paranhana”. Before this study was conducted, it was approved by the Ethics in Research Committee of Faculdades Integradas de Taquara-FACCAT. After approval of the project, contact was made with the Therapeutic Communities of Vale do Paranhana, RS in order to present the project and request authorization, through a term of agreement, to carry out the research in their facilities. Based on this agreement, the therapeutic communities informed the researcher when a user was finishing his treatment, i.e. was about to be released. At this time, two trained researchers went to the TC to conduct the interview and apply the socio-economic questionnaire which contains the questions that are relevant to this study. The researchers explained the developed research to participants, laying out the reasons and clarifying doubts, and then presented the Free and Informed Consent Agreement (TCLE in the Portuguese acronym) - which, after being read and understood, was signed by the participant and researcher, allowing the collection of data. The interview was conducted on the TC, respecting the possible schedules and the available space, and lasted approximately one hour. The interviews were recorded for transcription and analysis at a later time.

\subsection{Procedures for Data Analysis}

The recorded interviews were transcribed and then analyzed by the Content Analysis process suggested by Maxwell and Miller (2008). This process follows these steps: a) reading of the transcripts of the data recorded in the interview to try to establish categories and relations between the data; b) Identification of the data that may be used in the analysis process, i.e., data that are relevant to the study; c) Segmentation of the data in order to analyze the categories; d) Analysis of the categories; e) Understanding of the categories in the context of the interview. It is important to emphasize that this order is not sequential, i.e., it is possible to go forward or backward between the steps. This enables us to understand the data in a rich, deep and contextualized way.

\subsection{Ethical Procedures}

The research followed the ethical principles that govern research with human beings-Resolution no. 196/96 (CNS, 1996). Data collection was started after approval by the Committee for Ethics in Research of the Faculdades Integradas de Taquara (Number 268/2012) and according to the instructions from the Therapeutic Communities regarding the data collection.

\section{Analysis and Discussion of Results}

After completing the content analysis of the interviews, the participant's responses were grouped into six categories (Table 2): 
Table 2. Description of Categories and subcategories.

\begin{tabular}{|c|c|}
\hline Category & Subcategory \\
\hline Category $1-$ Expectations or plans for the future & $\begin{array}{l}\text { 1.1 Studying } \\
\text { 1.2 Meeting the expectations of family } \\
\text { 1.3 Working with drug addiction } \\
1.4 \text { New friendships } \\
1.5 \text { New habits }\end{array}$ \\
\hline Category 2-Family & $\begin{array}{l}\text { 2.1 Support/acceptance } \\
\text { 2.2 Regaining trust } \\
\text { 2.3 Improving communication }\end{array}$ \\
\hline Category 3-Friendships & $\begin{array}{l}\text { 3.1 New friendships } \\
\text { 3.2 Difficulty in maintaining old friendships } \\
\text { 3.3 Rejection of friends }\end{array}$ \\
\hline Category 4—Professional Life & $\begin{array}{l}\text { 4.1 Working with a drug addiction } \\
\text { 4.2 Seeking employment/ return to work } \\
\text { 4.3 Changing the professional focus } \\
\text { 4.4 Acquiring/retrieving things }\end{array}$ \\
\hline Category 5-Reintegration Strategies & $\begin{array}{l}\text { 5.1 Social life/adapting to society } \\
\text { 5.2 Attending healthy environments } \\
\text { 5.3 Searching for God and the church } \\
\text { 5.4 Attending support groups } \\
\text { 5.5 Geographical change }\end{array}$ \\
\hline Category 6-Actions regarding the Craving & $\begin{array}{l}\text { 6.1 Calling/talking with friends } \\
\text { 6.2 Diverting the focus/moving in the opposite direction } \\
\text { 6.3 Seeking professional/TC help } \\
\text { 6.4 Avoiding places of use } \\
\text { 6.5 Turning back/ crossing the street } \\
\text { 6.6 Taking medication }\end{array}$ \\
\hline
\end{tabular}

\subsection{Category 1: Expectations or Plans for the Future}

Category 1 concerns the expectations or plans for the future experienced by the drug addicts. It can be divided into five subcategories: studying, meeting the expectations of family, working with a drug addiction, new friendships and new habits.

One of the challenges of recovery is to replace the routine of use by new habits that avoid a relapse to previous behavior. The social environment is of great influence on recovery, as are the social life with recovered colleagues who are seen as friends, family life and the professional support structure (Rigotto \& Gomes, 2002). The rehabilitation plan must have goals, strategies and objectives that will be addressed during the rehabilitation process. This plan should be developed with the patient so that it can be built around his positive points (Bonadio, 2011). The drug addict should therefore take on an active role in the beneficial restructuring of the social support for himself, seeking other paths in life, such as leaving behind addicted friends by refusing offers for use (Pinho et al., 2008). This can be seen in the following statements: "I am creating a new circle of friends, and sometimes it is a little difficult (...) sometimes I go out this way and I can't relate well with people". (P2), "I want to be involved with healthy people, look for other places, other habits" (P10).

\subsection{Category 2: Family}

Category 2 concerns the expectations the drug addict has with regards to his family after finishing the treatment. It can be divided into three subcategories: support/acceptance, regaining trust and improving communication.

According to Rigotto and Gomes (2002), family, self-help groups, shared experiences with recovered friends, religion and psychological monitoring have been acknowledged as a source of support during recovery. The presence of the family has also been identified as positive support in rehabilitation. 
According to Beck Jr. (2010), drug addiction causes significant changes in the interaction of the addict with his professional and, in particular, his family relations. Crack can be seen as a major disruptor of families that destroys the relationship of the individual with his entire network. After treatment, patients seek to redeem these relations and to regain the trust of family members. These factors can be observed in the respondents' statements: "My family members were the ones who helped me (...), my family is OK now" (P3), "I had nothing, I'd lost even the trust of my family" (P4), "I'm in a very good place with my family, I am able to speak with my father now, before we didn't speak" (P1). Family is a fundamental part of the treatment process and it is very important for the social reintegration process. The way in which the addict is taken in and how relations are established between him and his family are very important for his emotional and social restructuring. It will provide the conditions for him staying abstinent (Costa, 2001).

\subsection{Category 3: Friendships}

Category 3 points to the expectations of the drug addict regarding friendships. It is divided into three subcategories: new friendships, difficulty in maintaining old friendships and rejection of friends.

Breaking the cycle of drug use is very complicated and difficult because addiction is accompanied by much physical and mental suffering, affecting not only the addict's life, but also that of his friends, family and the community in a general (Pratta \& Santos, 2009). Recent studies have shown that the negative effects of the drug on friends and relatives, in addition to the physical damage and the inability to achieve goals, are seen by the user as inhibiting factors for the use of drugs (Sayago, 2011). This information indicates that friendships are an important factor for the user because they may be a protective factor for the use of drugs. This can be observed in the following reports: "My expectations are the best possible because these are new friends, these are friends with the same purpose as I" (P1), "The friends that I have are those who are in treatment, in recovery, I cut ties with my old friends, those who grew up with me" (P7).

\subsection{Category 4: Professional Life}

Category 4 brings together the desires and expectations of drug addicts regarding their professional life. This category can be divided into four subcategories: working with drug addiction, seeking employment and/or returning to work, changing the professional focus and acquiring and/or retrieving things.

Therapeutic communities are drug free environments with a hierarchical model that reflects the increasingly higher levels of personal and social responsibility of the patient. Their objective is to develop more effective skills for dealing with drug addiction (Sabino \& Cazenave, 2005). For addicts, working with drug addiction means they can better understand the disease, in addition to having a professional occupation, which is reflected by this sentence expressed by Participant 1: "I hope to work and study a lot, given that it is a new field and that I have little experience with drug addiction".

Because crack hinders any activity that demands responsibility, the crack users have great difficulty in maintaining a job, which means a greater number of unemployed among crack users (Filho Turchi, Laranjeira, \& Castelo, 2003). From this last statement we can infer that the distrust of employers leads to a greater difficulty of the addict finding a position in the labor market again. Guimarães, Santos, Freitas \& Araujo (2008) also state that the majority of crack users has no formal employment or is unemployed, aggravating the problem of crack addiction. This can be seen clearly in the following statements: "I want to go back to work, but I still don't have a destination, I will look for employment" (P5), "I changed my professional focus (...) because my former employment was a facilitator for my addiction” (P2).

\subsection{Category 5: Reintegration Strategies}

Category 5 refers to the reintegration strategies used by drug addicts in this phase of treatment. It can be divided into five subcategories: social life and/or adapting to society, attending healthy environments, seeking God and the church, attending support groups, and geographical flight.

A Self-Help group can show new possibilities of existence through the shared experiences of the advantages of living in abstinence, in the same way that the support of colleagues in recovery can help prevent new relapses (Rigotto \& Gomes, 2002). This statement is confirmed by the report of participant 7 "whenever I can, I go to NA or meetings offered by the CAPS for drug users". 
According to Ribeiro and Bogar (2011), religiosity, no matter what the religion, can help in the recovery of drug addicts and help them to remain abstinent. The increase in optimism, resiliency, and the reduction of anxiety, are factors that are stimulated by religiosity and help in the recovery of drug addicts. This statement is confirmed by the following report: "Seeking God, the church (...) seeking the church, always being home" (P5).

Religious communities and spiritual communities can facilitate social reintegration, because they provide stability, inspiration and support to its members (Ribeiro \& Bogar, 2011). Bonadio (2011) says that it is essential for the individual to develop skills during treatment that will help him to reintegrate into work, school, housing, family relations, social networks, and leisure activities, among other factors that may affect the rehabilitation. Social support during treatment of the drug user can improve the interpersonal interaction of users and society, helping him to keep abstinent and to take on a new social role (Pinho et al., 2008).

\subsection{Category 6: Actions Regarding the Craving}

Category 6 refers to how the drug addict expects to act regarding his craving. It is divided into six subcategories: calling/talking with friends, diverting the focus and/or moving in the opposite direction, seeking professional and/or TC help, avoiding places of use, turning back/ crossing the street and taking medication.

Araujo and colleagues (2008) state that the craving is an individual experience, that requires customized strategies to be controlled and/or managed. He says that distractions (Ex: engaging in some activity), refocusing (thinking about something incompatible with drug use) and physical exercise, among others, can be used as strategies to reduce the craving or withdrawal symptoms. These strategies are also mentioned by the respondents: "Look for someone to talk, avoid or divert the thoughts, go do something else, not keep thinking about it" (P8), "Avoid places, avoid going to some place that is conducive to drug use (...) quickly think of something else to do" (P3).

The use of psychotropic drugs in order to manage the craving has been the focus of research. Few, however, have proven to be effective in controlling the craving, not excluding the use of other techniques (Araujo et al., 2008). Soussumi (2012) stresses that crack users, in particular, have very severe abstinence crises, even after long periods of hospitalization and treatment, which means they require exceedingly long term treatment.

\section{Concluding Remarks}

This study sought to investigate the perspectives of crack users regarding their social reintegration after the end of their treatment in therapeutic communities. The proposal was to explore the perspectives and, despite its limitations, the study contributed significantly to the understanding of the issue of social reintegration of crack users.

Several factors emerged regarding the expectations and plans for the future that are important for the drug addict, such as the desire to pick up his studies to better understand his disease and improve his knowledge. Meeting the expectations of family and being accepted by them is a very important factor for patients. Making new friends and developing new habits to be able to rebuild his life and, consequently, remain abstinent are also important aspects for the dependents.

Family has earned a separate category, showing once more how important it is for treatment and the maintenance of abstinence. Factors such as acceptance, regaining the confidence of children and parents and the support of family members are cited often. Family is a subject that brings up a lot of emotion. According to the participants, they are the party involved that has suffered most because of their addition. This also makes these relations more difficult to be recovered and restructured. These data are corroborated by Schenker and Minayo (2004) who point to the central role of family in the treatment of drug addiction.

Another factor that draws attention is friendships. All participants speak of new friends who are not addicted. The old friendships are seen as risk factors and represent a danger to them because they are potential triggers for use. This reason is also related to the difficulty in maintaining ties with the former friends of the addiction. There are reports of distrust in the friendships they had before becoming addicted. These friends have lost confidence because of dangerous and uncomfortable situations in which they were involved due to the drug addiction.

For most addicts, professional life is still a great challenge. Many want to keep working within the therapeutic community. Here they can also learn more about drug addiction and new strategies to deal with drugs. We ob- 
served that the permanence in the therapeutic community ends up being a form of protection, because it is an environment that protects against drugs and the whole criminal circle surrounding it.

As for the reinsertion strategies that they cite, it is possible to observe a scarcity of options. This may be because they are still cognitively poor in ideas because of the drug use and because they have lived for a long time in isolation in the therapeutic community. Even so, the strategies that appear are adaptive, such as attending healthy environments and self-help groups. One strategy that drew a lot of attention was geographical change, which would imply that the addicted person cut all ties with the sick environment in which he lived and that he move geographically. This would allow him to build new friendships and new ties in the hope that this change can bring healthier habits.

The craving is something that is very present in the lives of the respondents and of addicts. We could observe that the actions regarding the craving still need to be improved and better adapted to ensure that they can remain abstinent. It is known that the craving, in the majority of cases, is constant throughout an addict's life. It needs to be further addressed and trained during the treatment so that, when the addict returns to live in environments that can trigger use, he'll possess alternatives to handle his craving.

This paper contributes in social terms for therapeutic process, since it points to several factors that surround the recovery of drug addicts. Such understanding is relevant to enable the development of new techniques to assist in the recovery phase. This phase of the treatment has still limited studies and the professionals that deal with dependency don't comprehend very well the long term effects of crack use. More studies are required to increase the knowledge of these consequences. Finally, longitudinal studies must be performed that monitor drug addicts after their discharge from the therapeutic community.

\section{Acknowledgements}

We thank the Conselho Nacional de Desenvolvimento Científico e Tecnológico (CNPq) [National Counsel of Scientific and Technological Development] for financial support of the research. And also thank all colleagues from Research Group in Community Psychology—Saúde.com—from Integrated Faculties of Taquara (FACCAT) that help in the data collection.

\section{References}

Alves, H. N. P., Ribeiro, M., \& Castro, D. S. (2011). Cocaína e Crack [Cocaine and Crack]. In: A. Diehl, D. C. Cordeiro, \& R. Laranjeira (Eds.), Dependência Química [Chemical dependency] (pp. 170-179). Porto Alegre: Artmed.

American Psiquiatric Association (2002). DSM-IV-TR. Manual Diagnóstico e Estatístico de Transtornos Mentais [DSM-IVTR-Diagnostic and Statistical Manual of Mental disorders] (4th ed). Porto Alegre: Artmed.

Araujo, R. B., Oliveira, M. S., Pedroso, R. S., Miguel, A. C., \& Castro, M. G. T. (2008). Craving e Dependência Química: Conceito, Avaliação e Tratamento. [Craving and Chemical Dependence: Concept, Evaluation and Treatment]. Psychiatric Brazilian Journal, 57, 57-63. http://www.scielo.br/pdf/jbpsiq/v57n1/v57n1a11.pdf

Araujo, R. B., Pansard, M., Boeira, B. U., \& Rocha, N. S. (2010). As Estratégias de Coping para o Manejo da Fissura de Dependentes de Crack [Coping Strategies for Craving Management in Crack Dependents]. Revista HCPA, 30, 36-42. http://seer.ufrgs.br/hcpa/article/view/11572/7509

Bardin, L. (1977). Análise de conteúdo [Content Analysis]. Lisboa: Edição 70.

Bechelli, L. P. C., \& Santos, M. A. (2001). Psicoterapia de grupo: Noções básicas [Group Psychotherapy: Basic notions]. Ribeirão Preto, SP: Legis Summa.

Beck Jr., A. (2010). Dependência do Crack: Repercussões Para Usuários e Sua Família [Crack Dependence: Repercussions in the Users and Their Families]. Graduation Conclusion Unpublished Work. http://www.lume.ufrgs.br/bitstream/handle/10183/24707/000748967.pdf?sequence=1

Blefari, A. L. (2002). A Família e a Drogadição [Family and Drugaddiction]. http://www.sobresites.com/dependencia/pdf/Familia_e_a_Drogadiccao.pdf

Bonadio, A. N. (2011). Reabilitação Psicossocial. [Psychosocial Rehabilitation]. In: A. Diehl, D. C. Cordeiro, \& R. Laranjeira (Eds.), Dependência Química [Chemical Dependency] (pp. 267-273). Porto Alegre: Artmed.

Costa, L. G. (2009). A rede de Apoio Social de Jovens em Situação de Vulnerabilidade Social e o Uso de Drogas [The Social Support Network for Youth in Situations of Social Vulnerability and Drug Use]. Master Thesis (Unpublished), UFRGS: Programa de pós-graduação em Psicologia. http://hdl.handle.net/10183/16339

Costa, S. F. (2001). O Processo de Reinserção Social do Dependente Químico Após Completar o Ciclo de Tratamento em 
Uma Comunidade Terapêutica [The Process of Social Welfare in Chemical Dependents After Completing the Cycle of Treatment in a Therapeutic Community]. Serviço Social em Revista, 3, 215-242.

http://www.uel.br/revistas/ssrevista/c_v3n2_processo.htm

Duailibi, L. B., Severino, R., Barbosa, V. M. M., \& Ribeiro, M. (2012). Reabilitação Psicossocial e Gerenciamento de Caso [Psychosocial Rehabilitation and Case Managementt]. In: M. Ribeiro, \& R. Laranjeira (Eds.), O Tratamento do Usuário de Crack [Crack Users Treatment] (pp. 434-446). Porto Alegre: Artmed.

Filho, O. F. F., Turchi, M. D., Laranjeira, R., \& Castelo, A. (2003). Perfil Sócio Demográfico e de Padrões de Uso Entre Dependentes de Cocaína Hospitalizados [Epidemiological Profile of Cocaine Users on Treatment in Psychiatrics Hospitals, Brazil]. Revista de Saúde Pública, 37, 751-759. http://www.scielo.br/pdf/rsp/v37n6/18018.pdf http://dx.doi.org/10.1590/S0034-89102003000600010

Fracasso, L. (2011). Comunidades Terapêuticas [Therapeutical Communities]. In: A. Diehl, D. C. Cordeiro, \& R. Laranjeira (Eds.), Dependência Química [Chemical Dependency] (pp. 61-69). Porto Alegre: Artmed.

Gomes, J. C. V. (1997). Manual de psicoterapia Familiar [Manual of Family Psychotherapy]. Petrópolis: Vozes.

Guimarães, A., \& Aleluia, G. (2012). Intervenção Familiar no Tratamento do Dependente de Crack [Family Interventions in Crack Dependent Treatment]. In: M. Ribeiro, \& R. Laranjeira (Eds.), O Tratamento do Usuário de Crack [Crack Users Treatment] (pp. 420-431). Porto Alegre: Artmed.

Guimarães, C. F., Santos, D. V., Freitas, R. C., \& Araujo, R. B. (2008). Perfil de Usuários de Crack e Fatores relacionados à Criminalidade em Unidade de Internação Para Desintoxicação no Hospital Psiquiátrico São Pedro de Porto Alegre [Profile of Crack Users and Factors Related to Criminality at the Detoxication Ward at Hospital Psiquiátrico São Pedro, Porto Alegre, Brazil]. Revista de Psiquiatria do Rio Grande do Sul, 30, 101-108. http://www.scielo.br/pdf/rprs/v30n2/v30n2a05.pdf

Macedo, M. M. K., \& Carrasco, L. K. (2005). Contextos de entrevista: olhares diversos sobre a interação humana [Interview Contexts: Different Views upon Human Interaction]. São Paulo: Casa do Psicólogo.

Marlatt, G. A. (1999). Redução de Danos: Estratégias Práticas para lidar com Comportamentos de Alto risco [Damage Reduction: Practical Strategies for Dealing with High-Risk Behavior]. Porto Alegre: Artmed.

Maxwell, J., \& Miller, B. (2008). Categorizing and Connecting Strategies in Qualitativa Data Analysis. In: S. N. Hesse-Biber, \& P. Leavy (Eds.), Handbook of Emergent Methods (pp. 461-477). New York: Guilford Press.

Mayer, L. R. (2002). Rede de Apoio Social e representação mental nas relações de Apego de Meninas Vitimas de Violência Domestica [Social Support Network and Mental Representation in Bond Relations in Girls that Suffer Domestic Violence]. Unpublished Ph.D. Dissertation, UFRGS: Pós-graduação em Psicologia. http://hdl.handle.net/10183/2793

Minuchin, S. (1990). Famílias, Funcionamento e tratamento [Families, Functioning and Treatment]. Porto Alegre: Artes Medicas.

Nonticuri, A. R. (2010). As Vivencias de Adolescentes e Jovens Com o Crack e Suas Relações Com as Políticas Sociais Protetoras neste Contexto [Adolescents and Youth Experiences with Crack and Their Relations with Protective Social Policies]. Unpublished Master Thesis, Programa de Pós graduação em Política Social, Universidade Católica de Pelotas. http://biblioteca.ucpel.tche.br/tedesimplificado/tde_busca/arquivo.php?codArquivo=223

Palomar Lever, J., \& Cienfuegos Martínez, Y. I. (2007). Pobreza y apoyo social: Un estudio comparativo en tres niveles socioeconómicos. Interamerican Journal of Psychology, 41, 177-188. http://pepsic.bvsalud.org/scielo.php?script=sci_arttext\&pid=S0034-96902007000200008\&lng=pt\&tlng=es

Payá, R. (2011). Terapia Familiar [Family Therapy]. In A. Diehl, D. C. Cordeiro, \& R. Laranjeira (Orgs.) (Eds.), Dependência Química [Chemical Dependency] (pp. 319-327). Porto Alegre: Artmed.

Perrenoud, L. O., \& Ribeiro, M. (2012). Histórico do Consumo de Crack no Brasil e no Mundo [History of Crack use in Brazil and in world]. In M. Ribeiro, \& R. Laranjeira (Orgs.) (Eds.), O Tratamento do Usuário de Crack [Crack Users Treathment] (pp. 33-49). Porto Alegre: Artmed.

Pinho, P. H., Oliveira, M. A., \& Almeida, M. M. (2008). A reabilitação Psicossocial na Atenção dos Transtornos Associados ao Consumo de Álcool e Outras Drogas: Uma Estratégia Possível? [The Psychosocial Rehabilitation of Individuals with Alcohol and Drug Use Disorders: A Possible Strategy?]. Revista de Psiquiatria Clínica, 35, 82-88. http://www.scielo.br/pdf/rpc/v35s1/a17v35s1.pdf http://dx.doi.org/10.1590/S0101-60832008000700017

Pratta, E. M. M., \& Santos, M. A. (2009). O processo Saúde-doença e a dependência química: Interfaces e evolução [The HealthIllness Process and the Chemical Dependence: Interfaces and Evolution]. Psicologia: Teoria e pesquisa, 25, $203-211$. http://www.scielo.br/pdf/ptp/v25n2/a08v25n2.pdf

Raupp, L. M. (2006). Adolescência, Drogadição e políticas Públicas: Recortes no Contemporâneo [Adolescence, Drug-Addiction and Public Policies: Views in Contemporaneity]. Unpublished Master Thesis, Porto Alegre: Pós-graduação em Psicologia Social e Institucional, UFRGS. http://hdl.handle.net/10183/9985

Ribeiro, H., \& Bogar, M. (2011). Espiritualidade e Dependência Química [Spirituality and Chemical Dependency]. In A. 
Diehl, D. C. Cordeiro, \& R. Laranjeira (Orgs.) (Eds.), Dependência Química [Chemical Dependency] (pp. 177-184). Porto Alegre: Artmed.

Rigotto, S. D., \& Gomes, W. B. (2002). Contextos de Abstinência e de Recaída na Recuperação de Dependência Química [Contexts of Abstinence and Setback in the Recovery of Chemical Dependence]. Psicologia: Teoria e Pesquisa, 18, 95106. http://www.scielo.br/pdf/ptp/v18n1/a11v18n1.pdf

Sabino, N. D. M., \& Cazenave, S. O. S. (2005). Comunidades Terapêuticas Como Forma de Tratamento Para a Dependência de Substancias Psicoativa [Therapeutic Communities as an Alternative to the Psychoactive Substances Dependency Treatment]. Estudos de Psicologia (Campinas), 22, 167-174. http://www.scielo.br/pdf/estpsi/v22n2/v22n2a06.pdf

Salgado, C. R. S., \& Ribeiro, M. (2012). Reabilitação Neuropsicológica [Neuropsychological Rehabilitation]. In M. Ribeiro, \& R. Laranjeira (Orgs.) (Eds.), O Tratamento do Usuário de Crack [The Treatment of Crack Users] (pp. 459-467). Porto Alegre: Artmed.

Sayago, C. B. W. (2011). Características de Usuários de Crack Internados em Serviços Especializados de Porto Alegre [Characteristics of Crack Users in Specialized Services in Porto Alegre]. Unpublished Master Thesis, Porto Alegre: Programa de pós-graduação em Psicologia, PUCRS. http://hdl.handle.net/10923/4893

Schenker, M., \& Minayo, M. C. S. (2004). A Importância da Família no Tratamento do Uso de Drogas: Uma revisão de literatura [The Importance of Family in Drug Abuse Treatment: A Literature Review]. Cadernos de Saúde Pública, 20, 649-659. http://www.scielo.br/pdf/csp/v20n3/02.pdf http://dx.doi.org/10.1590/S0102-311X2004000300002

Silva, I. R. (2000). Alcoolismo e Abuso de Sustâncias Psicoativas: Tratamento, Prevenção e Educação [Alcoholism and Psychoactive Substances Abuse: Treatment, Prevention and Education]. São Paulo: Vetor.

Soussumi, Y. (2012). O usuário Envolvido Com o Trafico de Drogas [The User Involved with Drug Traffic] In M. Ribeiro, \& R. Laranjeira (Orgs.) (Eds.), O Tratamento do Usuário de Crack [The Treatment of Crack User] (pp. 598-606). Porto Alegre: Artmed.

Vargens, O. M. C., Brands, B., Adlaf, E., Giesbrecht, N., Simich, L., \& Wright, M. G. M. (2009). Uso de drogas ilícitas e perspectivas críticas de familiares e pessoas próximas, na cidade do Rio de Janeiro, Zona Norte, Brasil [Use of Illicit Drugs and Critical Perspectives of Drug Users’ Relatives and Acquaintances in Northern Rio de Janeiro (City), Brazil]. Revista Latino-Americana de Enfermagem, 17, 776-782. http://www.scielo.br/pdf/rlae/v17nspe/04.pdf http://dx.doi.org/10.1590/S0104-11692009000700004

Vianna, A. (2008). Para Além dos Paraísos Artificiais Há Tratamento Possível nas Toximanias? [Beyond Artificial Paradises, Is There Any Toxic-Dependence Treatment Possible?]. Polêmica, 23, 50-58. http://www.polemica.uerj.br/pol23/oficinas/artigos/lipis_4.pdf

WORLD HEALTH ORGANIZATION (2004). Neurociências: Consumo e dependência de substâncias psicoativas [Neurosciences: Use and Dependence of Psychoactive Substances]. Genebra: WHO.

Zimerman, D. E. (1997). Como Trabalhamos Com Grupos [How to Work with Groups]. Porto Alegre: Artes Médicas. 